\title{
The impact of stream nutrient loading on macrophytes and metaphyton in Conesus Lake, USA
}

\author{
Peter E. D’Aiuto, Joseph C. Makarewicz and Isidro Bosch
}

\section{Introduction}

During the summers of 2000, 2001 and 2002, the littoral zone of Conesus Lake $\left(40^{\circ} 54^{\prime} \mathrm{N}, 77^{\circ} 43^{\prime} \mathrm{W}\right)$ supported massive blooms of metaphyton, mostly filamentous green algae (Zygnema sp. and Spirogyra sp.). Extensive agricultural activity $(60-80 \%$ of the land use) within the lake's western subwatersheds is responsible for the loading of large quantities of nitrate (up to $1800 \mathrm{~g} / \mathrm{ha} /$ day) and total phosphorus (up to $34 \mathrm{~g} / \mathrm{ha} /$ day) into the lake during precipitation events (MAKAREWICZ et al. 2001). Large assemblages of $M$. spicatum and accompanying metaphyton growth were often located near stream mouths (Fig. 1) and a significant correlation existed between stream nutrient loading (total phosphorus, soluble reactive phosphorus and nitrate nitrogen) during pre- cipitation events and the standing crop of macrophytes (Fig. 2). To further evaluate the relationship between stream nutrient loading and growth of metaphyton, the hypothesis that stream effluent high in dissolved phosphorus and nitrate had a stimulatory effect on Conesus Lake metaphyton biomass was tested in situ in continuous flow incubation chambers.

Keywords: macrophyte, metaphyton, blooms, SRP, nitrate, nutrient loading

\section{Methods}

Metaphyton (Zygnema and Spirogyra, range: $0.23-1.5 \mathrm{~g}$ ) in incubation chambers (D'AIUTO 2003) placed in the littoral of Conesus Lake continuously

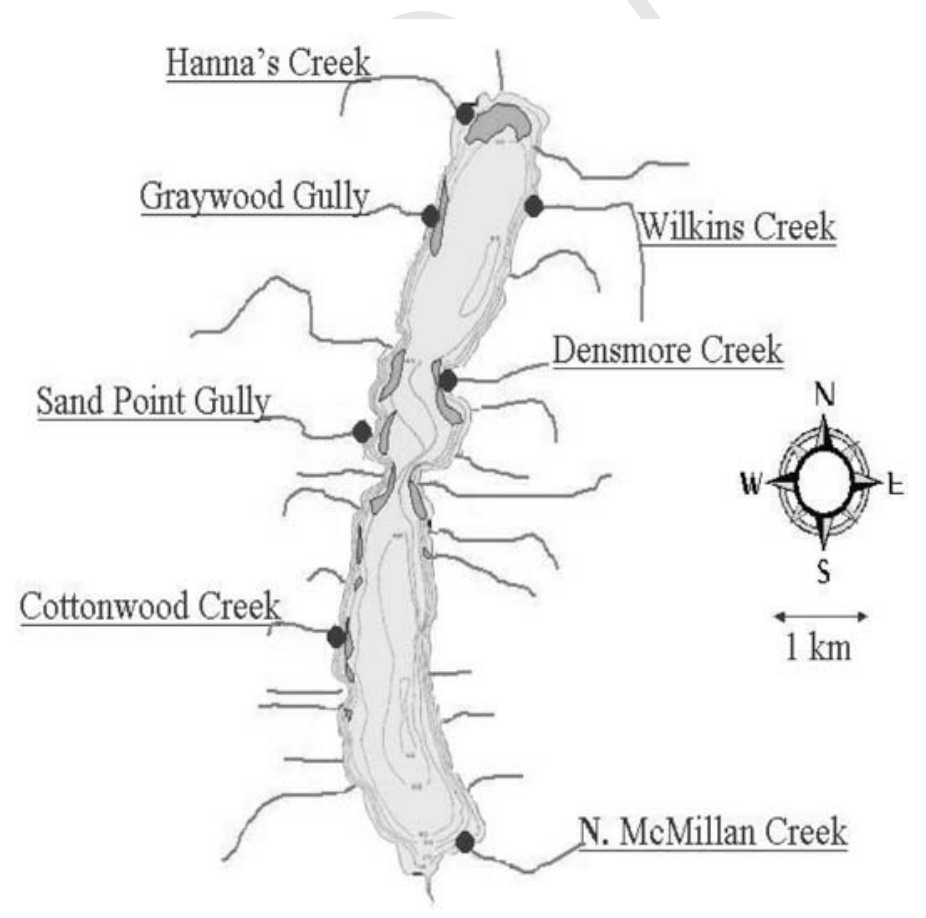

Fig. 1. Conesus Lake. Circles represent experimental Sites. Irregular areas near streams are GPS identified macrophyte beds. 


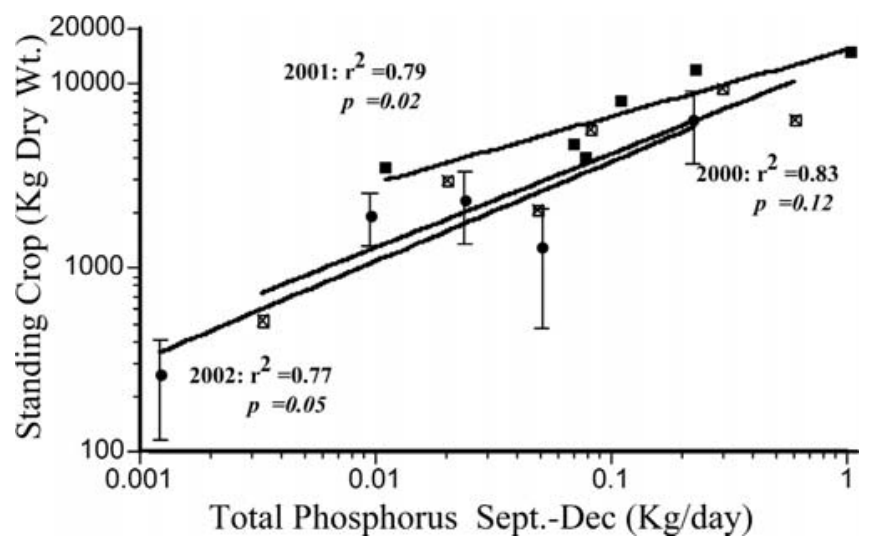

Fig. 2. Stream phosphorus loading from a stream versus macrophyte biomass at the mouth of the stream over a three-year period. Similar relationships exist for summer stream loading of phosphorus. received pumped stream effluent or lake (offshore) water. After a period of three days, metaphyton were removed, weighed and the percent growth was calculated. All incubation chambers were located in the littoral of Conesus Lake. However, one set $(n=4)$ received stream effluent while the second set $(n=4)$ received water pumped from the lake. In total, nine experiments were conducted using effluent water from seven different streams including one from a predominately forested watershed (North McMillan Creek) that served as our "nonagricultural" control. Because of differences in land use activity, an array of phosphorus and nitrate loadings from streams was available. Water samples were taken daily during experiments and analyzed for nitrate $\left(\mathrm{NO}_{3}\right)$ and soluble reactive phosphorus (SRP) by the automated cadmium reduction method and ascorbic acid method, re- spectively (APHA 1999). A Harvard Apparatus Peristaltic pump was used to deliver nitrate and SRP solutions into the incubation chambers $(1 \mathrm{ml} / \mathrm{min})$ in an additional set of nutrient enrichment experiments to determine nitrate or phosphorus limitation. Statistical comparisons were made with a t-test unless noted otherwise.

\section{Results}

Except for North McMillan Creek ( $\mathrm{P} \leq 0.47$ ), significantly higher percent growth in the stream-fed metaphyton chambers $(P \leq 0.02)$ was observed for all streams (Fig. 3). During all experiments, stream SRP concentrations were significantly higher than lake concentrations ( $P$

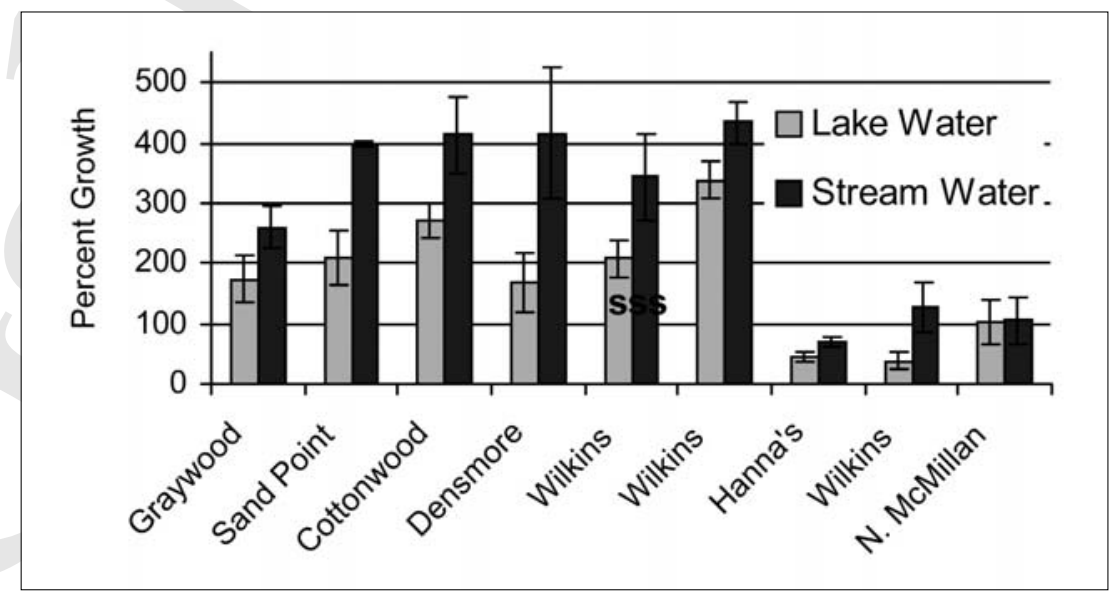

Fig. 3. Comparison of percent growth of metaphyton receiving stream effluent versus lake water. Names on $\mathrm{x}$-axis refer to creeks draining sub-watersheds. Error bars represent $\pm 1 \mathrm{SE}$. 
Table 1. Results of the nutrient enrichment experiments. Soluble reactive phosphorus and nitrate are averages for the 3-day incubation. Percent growth represents the average increase in metaphyton biomass over the study period.

\begin{tabular}{lccc}
\hline Addition & $\mathrm{SRP}(\mu \mathrm{g} / \mathrm{L})$ & $\mathrm{NO}_{3}(\mathrm{mg} / \mathrm{L})$ & $\%$ Growth \\
\hline $\mathrm{N}+\mathrm{P}$ & 12.63 & 1.33 & 124 \\
$\mathrm{P}$ & 12.20 & 0.07 & 135 \\
$\mathrm{~N}$ & 1.98 & 1.09 & 55 \\
control & 1.86 & 0.06 & 66 \\
\hline
\end{tabular}

$=0.05)$ with the exception of Hanna's Creek $(\mathrm{P}$ $=0.25)$ and North McMillan Creek $(\mathrm{P}=0.24)$. Stream nitrate concentrations were significantly higher than lake concentrations in five experiments. Although incubation chambers received stream and lake water that had the same nitrate concentrations, metaphyton biomass increased in the stream-fed chambers of Densmore Creek, Hanna's Creek and Wilkins Creek. North McMillan Creek had significantly higher concentrations of nitrate than lake waters $(P$ $=0.01)$, though no significant difference in metaphyton growth between the stream and lake experiments was evident. Temperature and $\mathrm{pH}$ differences between stream and lake-fed chambers were not statistically significant with one exception. Greywood Creek had significantly lower $\mathrm{pH}$ values $(\mathrm{P}=0.04)$ than adjacent lake water.

Experimental enhancement of SRP and $\mathrm{SRP}+\mathrm{NO}_{3}$ to lake water resulted in metaphyton growth $($ mean $=129 \%)$ that was significantly higher $(\mathrm{P}=0.002$, two-way ANOVA) than in chambers that received $\mathrm{NO}_{3}$ only or no nutrients above ambient levels (mean $=60 \%$ growth; Table 1). Metaphyton growth in chambers enriched with nitrate did not differ significantly $(\mathrm{P}=0.54$, two-way ANOVA) from growth in chambers that received no additional nitrate above ambient levels.

\section{Discussion}

The metaphyton incubation chamber experiments demonstrated that stream effluent promotes metaphyton (Spirogyra and Zygnema) growth in Conesus Lake. Metaphyton growth in chambers that received stream effluent (high phosphorus) was generally higher than meta- phyton growth in chambers that received lake water (low phosphorus). Where dramatic differences in growth of metaphyton occurred, experimental stream-fed incubation chambers had significantly higher concentrations of SRP resulting from the stream effluent. The exception was North McMillan Creek. Metaphyton growth in stream water from this primarily forested watershed was not significantly different $(\mathrm{P}=0.47)$ than that in chambers receiving lake water. This was an expected result as concentrations of SRP in both stream and lake water was not significantly different $(\mathrm{P}=0.24)$.

Because $\mathrm{pH}$ and temperature of stream and lake water were not significantly different, we propose that nutrients, specifically phosphorous rather than nitrate, was the cause of enhanced metaphyton growth observed in Conesus Lake. Metaphyton growth was significantly higher in the stream-fed chambers of Densmore Creek, Hanna's Creek and Wilkins Creek, even though nitrate concentrations between the effluent of these streams and corresponding lake water were not significantly different. Also, no significant difference in metaphyton growth occurred between the North McMillan streamand lake-fed chambers, even though significantly higher concentrations of $\mathrm{NO}_{3}$ were observed in the lake water compared to the stream water $(\mathrm{P}=0.005)$. Further corroboration of this hypothesis was provided by the nutrient enrichment experiments in which both nitrate and phosphorus levels were experimentally manipulated. Filamentous green algae growth was significantly lower in chambers receiving only nitrate than in those receiving phosphorus. Furthermore, interaction effects were insignificant ( $\mathrm{P}=0.99$, two-way ANOVA), suggesting that the effect of SRP on metaphyton percent growth was not influenced by the presence of $\mathrm{NO}_{3}$. Invariably, in the in situ incubation experiments, all chambers that yielded higher percent metaphyton growth received stream effluent containing higher SRP concentrations. It was evident that metaphyton biomass in Conesus Lake was strongly influenced by SRP levels. Other studies of fresh water bodies have demonstrated that filamentous green algae have flourished upon enrichment with phosphorus (DodDs and GUDDER 1992). MCCoRMick et al. (2001) demonstrated that fila- 
mentous green algae accumulated phosphorus rapidly and in proportion to the loading rate.

Why are filamentous green algae observed in the littoral, but not in the pelagic region of Conesus Lake? Metaphyton in Conesus Lake do not exist in high abundance in the littoral zone unless the rooted Eurasian water milfoil is present; that is, metaphyton appear to be limited by suitable substrate. Milfoil fronds provide anchorage up in the water column, preventing the algal filaments from sinking or from being washed ashore. Also, a shift toward filamentous metaphyton is suggested with nutrient enrichment (HAVENS et al. 1999, MCCORMICK et al. 2001). Physiological adaptations may offer competitive advantages for filamentous Zygnematalians. Larger cells (e.g. Spirogyra, Zygne$m a)$ can take up and store more nutrients than smaller cells; this ability can offer a competitive advantage during periods of nutrient scarcity (GRAHM \& WILCOX 2000). Additionally, cells in filaments have a competitive advantage over single cells because nutrients can be transferred between cells along the filament, from regions of high ambient nutrient concentrations to regions of low cellular concentrations (STEVENSON et al. 1985, RIBER \& WeTZEL 1987). Extensive agricultural applications of fertilizers and manure in the Conesus watershed provide an ample supply of phosphorus. During precipitation events, massive amounts of phosphorus and nitrate are delivered to the lake in short pulses of time (MAKAREWICZ et al. 2001). The dynamic between periodic (pulse) loading events and the ability of filamentous green algae to store nutrients has not been investigated, but periodic loading may offer a competitive advantage to filamentous green algae. Clearly, the physical, chemical and biological environment in littoral areas of Conesus
Lake, coupled with the adaptations of filamentous green algae, create an ideal scenario for the algae to flourish.

\section{References}

APHA, 1999: Standard Methods for the Examination of Waste and Wastewater. $19^{\text {th }}$ ed. - Amer. Public Health Assoc. Washington, D.C., USA.

D'Aiuto, P., 2003: The Impact of Stream Nutrient Loading on Metaphyton in Conesus Lake. - M.S. thesis. SUNY Brockport, Brockport, NY, USA.

DodDs, K.W. \& GUDDER, D.A., 1992: The ecology of Cladophora. - J. Phycol. 28: 415-427.

Graham, L.E. \& Wilcox, L.W., 2000: Algae. - Prentice Hall, Upper Saddle River, N.J.

Havens, K.E., EAst, T.L., Rodusky, A.J. \& Sharfstein, B., 1999: Littoral periphyton responses to nitrogen and phosphorus: an experimental study in a subtropical lake. - Aquat. Bot. 63: 267-290.

Makarewicz, J.C., Bosch, I. \& Lewis, T.W., 2001: Soil and Nutrient Loss from Selected Subwatersheds of Conesus Lake. - Prepared for the Livingston County Planning Department. Mount Morris, N.Y. Available from Drake Memorial Library, SUNY Brockport, Brockport, NY, USA.

McCormick, P.V., O’Dell, M.B., Shuford III, R.B.E., Backus, J.G. \& KenNedY, W.C., 2001: Periphyton responses to experimental phosphorus enrichment in a subtropical wetland. - Aquat. Bot. 7: 119-139.

RiBer, H.H. \& Wetzel, R.G., 1987: Boundary layer and internal diffusion effects on phosphorus fluxes in lake periphyton. - Limnol. Oceanogr. 32: 1181-1194.

Stevenson, R.J., Singer, R., Roberts, D.A. \& Boylen, C.W., 1985: Patterns of benthic algal abundance with depth, trophic status, and acidity in poorly buffered New Hampshire lakes. - Can. J. Fish. Aquat. Sci. 42: 1501-1512.

Authors' addresses:

Peter D'Aiuto and Joseph C. MaKarewicz, Department of Environmental Science and Biology, State University of New York at Brockport, Brockport, NY, 14420 USA.

IsIDRO BosCH, Department of Biology, SUNY Geneseo, Geneseo, NY, 14454 USA. 